frequently cut completely through the névé and expose the rock beneath to the action of frost. In such instances the rocks are in the best position possible to be acted upon by great changes of temperature. Dark bodies on high mountains absorb heat when exposed to the sun, although the air may be below $32^{\circ} \mathrm{F}$; and melting the adjacent snow, become saturated with water, which freezes as soon as they are in shadow. The blocks thus loosened fall away or are removed by the motion of the névé. The tops of the cliffs, however, are protected by a covering of snow. There is frequently a space above the top of the névé in summer which is exposed in like manner to the action of the atmosphere. Theseslopes recede by sapping through the action of frost, and precipices result. While the upper portions of the walls of depressions filled with névé snow are being broken away by the tensions in the névé, and by atmospheric action, the snow on the lower slopes is under compression, and thus rendered capable of abrading the rocks over which it flows.

The ice, in descending the steep slopes from various sides, impinges with great force on the bottoms of the depressions it occupies, and tends to scoop out rock basins. The result of these combined agencies is seen when the névé is removed, and we find amphitheatres with precipitous walls rising immediately above a rock basin lake. In other words, the resulting form is a cirque like those of the High Sierra.

So far as my observations extend, cirques are confined to mountains on which ice sculpture followed water sculpture. The topographic forms left after the disappearance of the ice are modifications of the antecedent forms due to the action of rain and streams.

In the vicinity of Mount St. Elias, Alaska, the mountain ranges are primarily monoclinal uplifts of geologically recent date, and do not bear evidence of having been deeply dissected by streams previous to the birth of the present glaciers. The ice drainage is largely consequent on the present orographic structure, and cirqu's are usually absent. One remarkable exception to this is furnished, however, by a fine cirque on the southern side of St. Elias, which is filled by névé snows and drained by a small glacier. Thousands of secondary and tertiary glaciers exist on the southern slopes of the mountains, but certainly very few, and so far as my knowledge goes none, of these have their origin in true cirques. On the north side of the mountairs, however, which are in general the gently sloping surfaces of orog taphic blocks, topographic forms inherited from former aqueou; ercision are conspicuous, and cirques are abundant.

Glaciers exist about the summit of Mount Shasta, Mount Ranier, Mount Baker, and other high volcanic peaks in the Cascade Mountains, but none of these, so far as known, originate in cirques. These mountains, like the uplifts about Mount St. Elias, are geologically young. They are volcanoes with fumaroles in their craters ; and owing to their elevation, and the comparatively slight erosion they have suffered, it is reasonable to suppose that the first precipitation on their summits was in the form of snow. Glaciers were formed on unmodified slopes, but have not excavated cirques for themselves. The glaciers on these mountains, like many of the smaller ice streams in Alaska, occur on exposed slopes and not in depressions. The accumulations of snow and ice form prominent convex surfaces and frequently give a characteristic outline to the summits which they cover.

The probable origin of cirques which I have traced, together with the fact that they occur in thousands about the summits of mountains on which the glaciers followed water sculpture, together with their absence on unglaciated mountains like the Southern Appalachians, and also the fact that glaciers in themselves do not seem to bave the power of excavating similar depressions, is seemingly cumulative evidence pointing to the conclusion stated above.

Cirques, alcoves, and possibly other forms, when considered simply as topographic features, may perhaps be classed together ; yet, genetically, alcoves and cirques are distinct, the former owing their existence to aqueous sculpture, usually in horizontal rocks, and the latter to aqueous sculpture followed by ice sculpture, in rocks which may be heterogeneous or homogeneous, horizontal or inclined.

The generalization that "cirques are confined to glaciated regions," to which $\mathrm{Mr}$. Bonney takes exception, was reached from considering the distribution of typical examples, previous to the differentiation of cirques from other similar topographic forms. When they are recognized as distinct from alcoves, and necessarily in part of glacial origin, the reason for their distribution becomes evident, as does also the further generalization that they "occupy localities where glaciers first appear."

In the Rocky Mountains the peaks and ridges on which cirques occur have an elevation of from 10,000 to 14,000 feet. The same is true also in the Sierra Nevada. In each of these regions the ancient névé fields had generally aboint the same elevation, while the glaciers flowing from them descend to within 6000 or 5000 feet above sea-level. In Alaska, however, where the former glaciers descended into the ocean, cirques occur on peaks and ridges only 3000 or 4000 feet high, and examples may be found at elevations of less than 2000 feet. Their vertical, as well as their geographic range, therefore, appears to have been regulated by the climatic conditions which control the birth of local glaciers.

While "alcove" and "cirque" should have a definite sig nificance in geology, amphitheatre, recess, bowl, and other correlative words, may be considered as general terms applicable to more or less inclosed spaces without reference to their origin. The semicircular recesses made by winding streams in the sides of cañons and deep valleys, sometimes resemble alcoves. Craters frequently bear a close topographic similarity to cirqucs, but are readily distinguished when their origin is considered.

On looking over my account of the cirques of the High Sierra (Eighth Annual Report, I886-87, U.S. Geological Survey), I fail to discern any reason for materially changing it, except, as indicated above, to state more definitely the differences between cirques and other topographic forms with which they might be confounded.

I remain very sincerely your friend,

ISRAFL C. RUSSELL.

\section{Large Meteor of January 24, I892.}

IT is to be hoped that further observations wlll be forthcoming of the brilliant meteor of January 24 , Ioh. $55^{\mathrm{m}}$. (described by Mr. T. Heath in your last number, p. 295), so that its real path may be computed. I think there is iittle doubt the meteor belonged to a shower of Draconids having a radiant. point a few degrees south-east of the star $\zeta$. On the same night (January 24) as that on which the fine meteor was observed, I saw a third magnitude shooting-star, at $7 \mathrm{~h} .55 \mathrm{~m}$., with a path from $324^{\circ}+40^{\circ}$ to $330^{\frac{1}{2}}{ }^{\circ}+31^{3^{\circ}}$, and this also belonged to the radiant in Draco. I discovered this shower on the nights of January 19 and 25,1887 , and determined the position of the radiant as at $261^{\circ}+63^{\circ}$. There are many other showers from the same point in the spring, summer, and autumn months.

Bristol, January $3 \mathbf{I}$.

W. F. DENNING

\section{On the Relation of Natural Science to Art.}

IN Dr. du Bois-Reymond's interesting lecture, as published recently in NATURE, there occurs the following passage (p. 226): "Flaxman" was "certainly mistaken in representing Polyphemus with three eyes-two normal ones which are blind, and a third in the forehead." Does not the recent discovery of a third (parietal) eye in some of the lizard and fish tribes (not to mention the tunicates!) diminish the force of this assertion? Flaxman's genius appears rather to have forestalled the discoveries of science in representing the human monster with three eyes, especially as Wiedersheim states that even in man nervefibre: have been traced from the optic thalami to the pineal gland.

$$
\text { W. Ainsite Hollis. }
$$

Brighton, January Ir.

\section{Ice Crystals.}

THE following account of some very well defined ice crystals may be of interest.

On December 26,1891 , the thaw set in. On the 27 th, I noticed on the surface of the ice on the lake at Drinkwater Park, near Prestwich, on the outskirts of Manchester, a large number of very distinct, hexagonal, tabular crystals. The surface of the ice was not very wet. These crystals varied from half an inch to three inches across, were raised about an eighth of an inch above the surface of the ice, and in many cases bore a similar but much smaller crystal in the middle, raised about an eighth of an inch above the surface of the larger crystal. In some specimens the smaller crystal was rounded and indis.

NO. I I 62 , VOL. 45$]$ 